International Journal of Advanced Academic Research | Arts, Humanities and Education | ISSN: 2488-9849

Vol. 6, Issue 6 (June, 2020) |www.ijaar.org

Journal DOI: www.doi.org/10.46654/ij.24889849

Article DOI: www.doi.org/10.46654/ij.24889849.a6699

\title{
GREEN POLITICAL IDEOLOGY AS AN IMPERATIVE FOR A SUSTAINABLE SOCIETY
}

\author{
Solomon Kolawole Awe \\ Department of Philosophy, \\ University of Ibadan, Nigeria. \\ awesolomon90@gmail.com
}

$\&$

Muhydeen Adekunle Adedoja

General Studies Department, Adeseun Ogundoyin Polytechnic, Eruwa, Nigeria.

lizzycom70@yahoo.com

\begin{abstract}
This paper aims to examine the nature of green political ideology. It is observed that the society is anthropocentric in its policy and decision making such that the society has little or no respect for non-human entities. Thus, this paper argues for a sustainable society which appreciate biodiversity in nature. Put otherwise, green political ideology is a reaction to some philosophical and political theories that undermines the value of the non - human natural world in the society. This paper maintains that there is a necessity for critical evaluation and revision of policies, laws and political implementations that have undermined and denigrated the non - human beings in the society. The paper concludes that a sustainable society does not only plan for the present but also project into the future for future generations and the society as a whole.
\end{abstract}

Keywords: Green Political Ideology, Anthropocentrism, Ecologism, Environmentalism, Sustainable Society. 


\section{Introduction}

The question of a good society has been a controversial issue discussed and debated over time from classical philosophy to contemporary period. Different political theories have been espoused as the ideal theory to attaining a good and ideal society. However, the question of a good society is unsettled amidst divergent political theories.

The society encompasses all humans and non - humans, different political institutions and civil society. Put otherwise, in a society, human existence is connected to the existence of other non - humans in the society. Hence, a sustainable society projectsand plans to keep safe the existence of humans and non - humans.

Thus, in contemporary society, the environment has been anthropocentric in its policy and decision making. Consequently, this however leads to the depletion and degradation of the natural environment for the benefit of humans. As such, the human - non human relationship is instrumental and not intrinsic. Perhaps, the non - human is created purposely for the benefit and use of humans. However, this anthropocentric inclination towards the world - view has been challenged by the greens.

The thrust of this paper is to underscore the whole gamut of discourse that centres on human - non human relationship from the green perspectives. In part because it is a new political ideology, there is no settled orthodoxy among the greens. It must be noted that an expository historical background to green political ideology is an imperative entry point. This presupposes that green political ideology is a reaction to some philosophical and political theories that undermines the value of the non - human natural world in the society.

We shall however maintain that there is a necessity for critical evaluation and revision of policies, laws and political implementations that have undermined and denigrated the non human beings in the society. We shall argue that a sustainable society does not only plan for the present but also projects into the future for future generations and the society as a whole.

Some of the key concepts we shall use includes ecologism, environmentalism, conservatism, anthropocentrism, holism and liberalism.

\section{Historical Development of Green Political Ideology}

Green political ideology presupposes a reactionary movement against the arbitrary domination of the humans over the non - human natural world. In fact, the rise of green political ideology is a response to the challenge of the so called environmental crisis such as global warming, resource depletion, localized production, decline in species, nuclear war, among others.

Green political parties and movements emerged in the 1970s. In terms of political influence and power control, the most successful green party is the 'German Green party'. ${ }^{1}$ Moreover, the German Greens as with other European Green parties draws its strength disproportionately from young, public sector, middle class workers, among others. ${ }^{2}$ The green movement encompasses more than just green political parties - conservation and environmental pressure groups are also important. Green political ideology self - consciously confronts dominant paradigms. By dominant paradigms, we mean post - industrial society as a 
technological affluent and service economy. ${ }^{3}$ Similarly, John Hoffman and Paul Graham posit that one explanation that is often advanced for the rise of the green ideology is the emergence of 'post - materialist values' and quality of life issues are more important than increasing income and enhanced career status. ${ }^{4}$

Even though green political ideology gained prominenceafter industrialized and scientific revolutions of the eighteenth and nineteenth centuries, environmental issues had been a long time problem that has been discussed in the classical world. Plato, Lucretius and Ceaser all commented on the problem of soil erosion. ${ }^{5}$ The collapse of the Mayan civilization hundreds of years ago can probably be attributed to deforestation and soil erosion. ${ }^{6}$ Moreover, the modern 'green debate' started with the 1962 publication of Silent Spring written by Rachael Carson. ${ }^{7}$ The book alerted readers to the connection between environmental and economic development, a promise that confronts and challenges today's dominant liberal ideology. ${ }^{8}$

There is no settled orthodoxy among greens. This implies that there are different classifications of greens ideology. Perhaps, one of the reasons green ideology has eluded clear classification is because it is composed of a diverse variety of environmental groups, parties and individuals that call themselves "Green". Thus, there are considerable differences among the Greens in terms of analysis, policy prescription and strategy. ${ }^{9}$ Put differently, there is no generally acceptable terminology in Green political ideology. In green ideology, distinctions have been drawn between darks greens and light greens, deep and shallow greens, ecologists and environmentalists, radicals and reformists, ecocentrics and technocentrics.

The above categorizations in green political ideology often overlap, needless to say, each has particular connotations and they are not necessarily interchangeable. Hence, green political ideology is not without objectives which are driving force against other contemporary ideologies that stand in contrast with green ideology. One of the objectives of green political ideology is the rejection of anthropocentric nature of world - view which, consequently is reflected in governmental activities and social policy. For further corroboration, Leach asserts that:

The green message is a stark one. It is that a continuation of unthinking and unlimited human exploitation of the natural environment spells disaster for the planet and for its human inhabitants. ${ }^{10}$

Another objective of green ideology is egalitarianism. To greens, the superiority imposition of humans over the non - human world is spurious and in-genuine. According to green thinking, nature possesses an intrinsic value, irrespective of whether or not it has value for humans.

For greens, the ecological crisis has exposed the extents to which liberal democracy has never questioned the domination of nature by humanity. This however is a rejection of liberal democracy because its principles and ideologies are anthropocentric. The greens not only reject liberal democracy, but also other political ideologies like socialism, capitalism, communism, among others. Moreover, the greens are known for their commitment to direct democracy. We may ask, does direct democracy or small government necessarily implythe non - exploitation of nature by humans? We shall return to this question in the later part of this paper. 
Green political ideology has been considered as a distinct ideology from other political ideologies. In the next section of this paper, we shall consider ecologism and environmentalism strands in green political ideology.

\section{Ecologism and Environmentalism as a Green Political Ideology}

Arne Naess is credited with coining the contrasting phrases deep ecology and shallow ecology. ${ }^{11}$ Now, the question is what is ecologism? Ecologism is a distinctive green political ideology encompassing those perspectives that hold that a sustainable society requires radical changes in our relationship with the non - human natural world and our mode of economic, social and political life. ${ }^{12}$ According to Dobson, what sets ecologism apart from political ideologies is its focus on the relationship between human beings and the non - human natural world. No other modern political ideology has this concern. ${ }^{13}$ As such, ecologism attempts to fault the human centred domination on the non-human world. Put otherwise, ecologists condemned the instrumental value attributed to nature by the human - world. However, nature should be seen as having intrinsic value which connotes an end in itself and not otherwise. As such, ecologist questions the fundamental basis of anthropocentrism. Naess espouses that "deep ecological thinking is not a slight reform of our present society, but a substantial re-orientation of our whole civilization. ${ }^{14}$

To the contrasting distinction between deep ecology and shallow ecology, deep ecology is often used synonymously with radical ecology. We shall discuss deep ecology in this paper mainly from the ideas popularized by Naess (1973); and Davall and Sessions (1984) and Dobson (1995). Deep ecology is distinguished from other ideological theories base on two normative principles. The first on one hand is to replace the anthropocentric bias of the Western world view which deep ecology regards as the fundamental cause of contemporary environmental problems and self - realization which entails an identification of self that goes beyond humanity to include the non - human world on the other hand. ${ }^{15}$

Deep ecology as an ideology rejects anthropocentrism in favour of ecocentrism or biocentrism. Deep ecologist proposes certain specific policy changes, such as population control and promoting biodiversity. This is premised on the claim that the earth is finite. Consequently, the earth naturally limits economic growth and population. This calls for a rethink of values in radical green agenda. It is however important to stress the word 'natural' because green ideologies argue that economic growth is prevented not for social reasons but because the Earth itself has a limited carrying capacity (for population), productive capacity (for resources of all types), and absorbent capacity (pollution). Meadows expresses this further that "growth of anything physical, including the human population and its cars and buildings and smoke stacks cannot continue forever. ${ }^{16}$ This further implies that the finitude of the Earth is the basic reason why infinite population and economic growth are impossible and consequently profound changes in our social and political behaviour need to take place. ${ }^{17}$ However, any attempt to solve the environment problem with the aid of technological fix is impossible. In the same vein, Meadow argues that we cannot expect technological solutions alone to get us out of this vicious circle ${ }^{18}$ and this has since become a central dogma of green politics.

According to Naess and Sessions, there are eight platform principles formulated to guide political activities and policy making in a society. They are: 
1. The well - being and flourishing of human and non - human life on Earth have value in themselves. (Synonyms: intrinsic value, inherent value). These values are independent of the usefulness of the non human world for human purposes. 2. Richness and diversity of life forms contribute to the realization of these values and are also values in themselves. 3. Humans have no right to reduce this richness and diversity except to satisfy vital human needs. 4 . The flourishing of human life and cultures is compatible with a substantial decrease of human population. The flourishing of non - human life requires such a decrease. 5. Present human interference with the non - human world is excessive and the situation is rapidly worsening. 6. Policies must therefore be changed. These policies affect basic economic, technological and ideological structures. The resulting state of affairs will be deeply different from the present. 7 . The ideological change is mainly that of appreciating life quality (dwelling in situations of inherent value) rather than adhering to an increasingly higher standard of living. There will be a profound awareness of the difference between big and great. 8. Those who subscribe to the foregoing points have an obligation to directly or indirectly try to implement the necessary changes. ${ }^{19}$

According to Dobson,ecologism makes the Earth as physical object the very foundation stone of its intellectual edifice grounded on the interrelationship and interdependence between the human world and non - human world.

Shallowecology, contrary to deep ecology or radical green ideology rejects ecocentrism and biocentrism. Shallow ecologists claim that there is nothing necessarily wrong with the anthropocentric worldview. Nature is only valuable in so far as it serves human interests. This however is sometimes known as instrumental value. This view, that is, shallow ecology is contrary to the radical green ideology. Barry expresses this in his thought that:

of particular importance is the central concern of green theory and practice to overcome both the separation of 'human' from 'nature' and also the misconception of humans as above or superior to nature. ${ }^{20}$

The shallow ecology is similar in its approach to environmentalism. Environmentalism according to Dobson argues for a managerial approach to environmental problems, secure in the belief that they can be solved without fundamental changes in present values or patterns of production and consumption. ${ }^{21}$ Thus, shallow ecology or environmentalism theory is compatible with some ideologies like liberalism and conservatism. In Dobson's view, the compatibility question depends entirely on one's terms of reference! Environmentalism and Liberalism are compatible, but ecologism and liberalism are not. ${ }^{22}$

Environmentalism does not reject the status quo of the political ideology of a state. In fact, it is believed that we can change the society without necessarily changing the government. As such, the idea of egalitarianism is unrealistic and impossible. To support this claim, Garrent 
argues using the metaphor of the 'Ethics of the lifeboat' which is basically grounded on uncontrolled population of the underdeveloped countries.

Hence, from the above distinction between ecologism and environmentalism, we contend that green political ideology is compatible with ecologism to environmentalism because green political ideology basically rejects the domination of human world over non - human natural world. That is, the rejection of anthropocentrism. By contrast, environmentalism is compatible with anthropocentricism. This however stands as the point of departure between ecologism and environmentalism. In this paper, we shall centre our discussion on ecologism as a green political ideology.

\section{Green Political Ideology and Sustainable Society}

Sustainable society is such that its members are able to meet their needs and express their greatest potential in the present, while preserving biodiversity and maintain these ideals for future generations. ${ }^{23}$ To the green ideology position, the limits to growth thesis therefore become imperatives. Nevertheless, Dobson posits three fundamental thoughts related to the limits to growth thesis. First, that technological solutions formulated within the bounds of present economic, social and political practices will not in themselves bring about a sustainable society; second, that the rapid rates of growth aimed for by industrialized and industrializing societies have an exponential character, which means that dangers stored up over a relatively long period of time can very suddenly have a catastrophic effect; and third, that the interaction of problems caused by growth means that such problems cannot be dealt with in isolation, that is, solving one problem does not solve the rest, and may even exacerbate them. ${ }^{23}$

Accordingly, technological solution is an impossible solution to the problem posed by industrialization. Hence, the question beckons, what is the possible solution to technological problem which has undermined the biodiversity in nature? For the greens, they suggest that a society orientated around sustainable growth would be a less greedy and more pleasant place to live. This however implies that consumption of material goals by individuals in advanced industrial countries should be reduced. This is grounded on the nature of the rate of growth. Conversely, Jonathan opines that 'if you want one simple contrast between green and conventionally politics, it is our belief that quantitative demand must be reduced, not expanded'. ${ }^{24}$ As such, greens argue that if there are limits to growth then there are limits to consumption as well.

Sustainable society premised on the limit to consumption espoused for a less materialistic society. In other words, the sustainable society according to Dobson is picturedas a replacement for consumer society which would provide for wider and more profound forms of fulfilment than that provided by the consumption of material objects. ${ }^{25}$

From the above discussion thus far, the greens maintain that long - term global sustainability involves population reduction basically on the grounds that fewer people will consume fewer objects. In Irvine and Ponton's view, 'the best resources policies are doomed to failure if not linked to population policy'. ${ }^{26}$ consequently, we may ask, can we absolutely do without technology? Is sustainable society self - sufficiently independent of technology? We shall answer negatively. The world has been developed to a level that technology is inseparable 
from development. In fact, the same technology is used to preserve and protect natural environment. However, we are not oblivious of the damages or negative effect of technology to the society, nevertheless, the absolute rejection of technology by the greens is not viable and tenable.

Moreover, it seems that the greens are more concerned about population control and consumption limitation and neglect the sources and provision of resources. It is possible to have a few populations in a society and yet, it will be difficult to access material objects for consumption. Shortly, we believe that there should be a change in subject matter of the greens from over emphasis on population to the sources and provision of resources. The reason for this assertion is that a political society is incomplete without the people. Hence, the survival of the populace should be prioritized over the governing and decision making policy. Even though, political ideology concepts to govern a particular society is welcomed as no society exists without an ideology. Needless to say, over prioritization of ideological concepts over human existence is like a smoke without fire which however seems impossible.

In addition, the greens have also been criticized for internal differences and divergences in theories. Greens political ideologists do not agree on what should constitute sustainable society, even though, they agree on certain assumptions.

\section{Green Political Ideology and Other Ideologies}

In this section, we shall give an explicative comparative analysis between green political ideology and other ideologies like liberalism, socialism, conservatism, anarchism and Democracy. Their point of convergence and divergence shall be critically underscored.

\section{Conservatism and Green Political Ideology}

Conservatism is a political philosophy which is averse to progressive change, oriented to the preservation of institutions and value and committed to tradition and authority. ${ }^{27}$ Conservatism is against radical change or revolutionary change. In other words, conservatism is not absolutely against the idea of change, rather change is a gradual process that evolves without forcing it. Hence, it is not against tradition, hierarchy and authority.

Similarly, like conservatism, some greens urge humans to be more humble and accommodating before nature, adapting to its laws, rhythms and putting less emphasis on exercising control over their environment and manipulating it to their own advantage. ${ }^{28}$ The greens are often sceptical and critical about the idea of progressive and innovative change which may alter the intrinsic value in nature and consequently lead to the depletion and degradation of the natural environment. As such, Martell argues that this gives ecology a distinctively conservative edge, emphasizing conservation and adaptation to the existing order rather than intervention and change. ${ }^{29}$ In the same vein, Lovelock argues that: 


\begin{abstract}
The awesome complexity and ability of nature to achieve balance and optimal conditions for sustaining life are sufficiently beyond our comprehension - yet to our benefit - that we are better advised to adapt to it rather than disturb it. ${ }^{30}$
\end{abstract}

However, there is much to green thought which makes it non - conservative and radical. ${ }^{31}$ Many greens call for radical changes in economic, political and social structure of the society. Many greens reject economic progress that altered the value of the non - human world; rejects political and decision - making policy which undermines and degrades the non - human world as instrumental to human ends. In contrast with conservative emphasis on authority and hierarchy, the radical greens strongly advocates for democracy and egalitarianism.

\title{
Liberalism and Green Political Ideology
}

Liberalism is a political philosophy committed to the rights and liberty of the individual. As such, it emphasises on the freedom and right of the individual in a society. Like liberalism, green ideology takes the liberal language of rights and obligations to its logical conclusions. ${ }^{32}$ Rights have been extended to all spheres of social, legal and political sector in the society. From liberal language of rights, greens extended right to future as well as present generations and to animals and other living and non - living organisms (animals, plants and maybe even rocks, stones and sand). Classical liberalists like J. S. Mill and Jeremy Bentham have extended rights to non human world. J. S. Mill on one hand advocates for stationary economy and Jeremy Bentham advocates for the extension of rights to animals as sentient beings.

However, there are points of divergence between liberalism and green political ideology. Liberalism emphasises on the principle of individualism, freedom for property acquisition, market freedom, promotion of economic growth and expansion and promotion of innovation and technology. By contrast, green ideology is committed to the resolution of environmental problems as a collective good, intervention and restrictions on economic and personal freedoms to deal with them. Also, the commitment to institutions of liberal democracy does not seem to fit well with strands in radical greens which seems either decentralised participatory democracy or centralised authoritarian survivalism. ${ }^{33}$ As such, greens require excessive restrictions on human freedom. Sustainability according to greens requires government to impose stiff restrictions on level of consumption, family size and individuals' freedom to pursue their preferred lifestyle. ${ }^{33}$

It could be inferred from green ideology that the proposals for restrictions on population, consumption and lifestyle is a significant loss of human freedom. On a final analysis, even though green political ideology did not totally agree with liberalism, however, it draws from them certain ideas to further its own analysis. 


\section{Marx-Socialism and Green Political Ideology}

In this section, we shall centre our discussion of socialism on Marxism. A number of scholars suggest that there are elements in the social theory of the early Marx which contribute to green political ideology and an environmental theorization of the relations between society and nature. Marx argues in his early writings that humans are not only psychologically internal but are also constituted in their relationships with the natural world. Marx opines that people work to transform their environment and in effect their environment affects their lifestyle. The realization of human potentialities and capabilities are embedded in nature. Consequently, human potentialities and capabilities will be distorted and unrealized if humans failed to interact with nature.

Marx argues that capitalism created alienation between the humans and the natural environment in which the natural environment is seen only as the 'other' to be explored and exploited for personal gain, profit and wealth creation. Put differently, capitalism sees nature as instrumental and a means to amass wealth property and economic prosperity. Thus, overcoming alienation involves restoring and rediscovering that nature should not be seen as instrumental value, rather as having intrinsic value in itself. This however will shape our behaviour and attitude towards nature as something of value in itself.

Socialist political economy further suggeststhat capitalist competition and economy dynamic expansion are the cause of environmental problems. In the effort to accumulate wealth, acquire property and make profit, natural resources are over - exploited and used, which consequently leads to pollution of the environment. Hence, to curb and resolve environmental pollution caused by capitalist greediness in pursuit of material resources, socialist political economy advocates for a shift in relations of production. Put otherwise, socialist suggests for a change in the productive forces. Martell argues that:

States acting on behalf of the general interest through legislation and enforcement provide a more realistic prospect for environmental change than decentralisation. Also, that it is problematic to see market rationality or capitalist self - interests as coinciding with a general interest in environmental protection. ${ }^{35}$

From the above quotation, ecological imperatives imply the priority of general interest, intervention and planning over self - interests, laissez - faire and market capitalism. ${ }^{36}$ However, green ideology challenges socialist theory on some other grounds. There are two problems against socialist theory. First, Marx's theory involves too heavy an emphasis on the human transformation of nature. That is, nature is seen as a medium for labour. ${ }^{37}$ In Martell's view, 
Marx's philosophy of history and social transformation and his theory of human nature recognise a dialectical relationship between humans and nature but one in which humans realise and transform themselves and their successive historical forms of social organisation in the transformation and exploitation of nature through labour and the development of productive forces. ${ }^{38}$

Second, Marx's conceptualization of the human - nature relationship is based on human betterment and not the well - being of non - human entitles or of nature itself. ${ }^{39}$ Thus, socialism is not redundant to green ideology, even though there are point of divergences as discussed above.

\section{Conclusion}

From our discussion thus far, we have been able to distinguish between ecologism and environmentalism. Ecologism is incompatible with anthropocentrism and presupposes radical changes in our relationship with the non - human natural world while environmentalism is compatible with anthropocentrism and presupposes a managerial approach to environmental problems without fundamental changes in patterns of production and consumption.

In furtherance of our argument, we argue that green political ideology is predicated on the theory of ecologism which rejects technological fix for environmental problem and advocatesfor reduction in population and less material consumption. However, the greens over emphasise the intrinsic value of nature. We may ask, in what ways should we consider nature as intrinsically valuable? In a case of cutting down a tree and planting another tree as a replacement, perhaps because the former tree has lost nutrient and is dying. The question is, have we not in this sense disregarded the intrinsic value in the tree for cutting it down? We argued that, the intrinsic attribution to non - human world is not clearly stated. Also, we argued that green ideology is too restrictive because it is more concerned with human - non human relationship and does not address some political problems like justice and liberty.

However, even though green ideology is not without criticisms, some positive contributions could be mentioned. First, green ideology is the only ideology that extends beyond human world to non - human world. In fact, non - human world has been conceived to be intrinsically valuable rather than instrumental. It has also rejectedthe exploitation of natural environment for wealth accumulation, profit and personal gain.

Although we do not see human and non - human to be equal, rather they are interrelated and interdependent, but we are against excessive and arbitrary use of natural environment to satisfy human curiosity. In other words, unnecessary use of the natural environment which consequently lead to wastage and pollution of the environment should be curtailed. Finally, natural environment should be considered in social policy and decision making. 


\section{Notes and References}

1. Hoffman, J. And Graham, P., 2006, Introduction to Political Ideologies. UK: Pearson Education Limited, p. 222

2. Ibid., p. 223

3. Marien, M., 1977. "The Two Visions of Post-Industrial Society" in Future 9 (5), pp. 416

4. Hoffman, J. And Graham, P., 2006, p. 223

5. See Wall, D., 1994. Green History: A Reader in Environmental Literature, Philosophy, and Politics. UK: Routledge Publisher.

6. See Ponting, C., 2007. A New Green History of the World: The Environment and the Collapse of Great Civilizations. London: Penguin Books.

7. Carson, R., 1962. Silent Spring. New York: Houghton Mifflin Company.

8. Humphrey, M., 2001. "Reassessing Ecology and Political Theory" in Environmental Practices, 10 , pp. $2-5$

9. Leach, R., 1996. "Green Ideology” in British Political Ideologies: Contemporary Political Studies Series. Palgrave, London, pp. $261-283$

10. Ibid.

11. Hoffman, J. And Graham, P., 2006, p. 226

12. Carter, N., 2001. The Politics of the Environment Ideas, Activism, Policy. UK: Cambridge University Press, p. 5

13. Dobson, A., 2007. Green Political Thought. $4^{\text {th }}$ ed., London: Routledge, p. 36.

14. Naess, A., 1989. Ecology, Community and Lifestyle: Outline of an Ecosophy. Trans. David Rothenberg, New York: Cambridge University Press, p. 45

15. Further reading, see Devall, B., and George, S., 1985. Deep Ecology: Living as if Nature Mattered. Salt Lake City, UT: Peregrine Smith; Naess, A., 1988. "Self-Realization: An Ecological Approach to Being in the World" in The Trumpeter 4(3), pp. 35 - 42.

16. Meadows, D. H., Meadows, D. L., and Jorgen, R., 1992. Beyond Limits: Confronting Global Collapse, Envisioning a Sustainable Future. White River, VT: Chelsea Green Publishing Company, p. 7

17. Dobson, A., 2007, p. 16

18. Meadows, D. L., and Meadows, D. H. et al., 1974. The Dynamics of Growth in a Finite World. Cambridge: Wright-Allen Press, Mass, p. 192

19. Naess, A., and Sessions, G., 1984. Basic Principles of Deep Ecology. www.deepecology.org, retrieved on $5^{\text {th }}$ August, 2017.

20. Barry, J., 2004. "Green Political Theory" in Political Ideologies: An Introduction. Eds. V. Geoghegan, and R. Wilford, London: Routledge, p. 154

21. Dobson, A., 2007, p. 2

22. Dobson, A., 2000. Green Political Thought. $3^{\text {rd }}$ ed., London: Routledge, p. 165

23. Dobson, A., 1995. Green Political Thought: An Introduction. $2^{\text {nd }}$ ed., London: Routledge, p. 165

24. Porrit, J., 1984. Seeing Green: The Politics of Ecology Explained. Oxford: Basil Blackwell, p. 136

25. Dobson, A., 2007, p. 19

26. Irvine, S., and Ponton, A., 1988. A Green Manifest. London: Macdonald Optima , p. 29 
Journal DOI: www.doi.org/10.46654/ij.24889849

Article DOI: www.doi.org/10.46654/ij.24889849.a6699

27. Martell, L., 1994. Ecology and Society: An Introduction. Cambridge: Polity Press. Chapter 5: pp. $1-25$

28. Ibid, p. 2

29. Ibid

30. Lovelock, J. E., 1989. The Ages of the Gaia. Oxford: Oxford University Press.

31. Eckersley, R., 1992. Environmentalism and Political Theory: Toward and Ecocentric Approach. London: University College London Press, pp. 21 - 22

32. See Naess, A., 1985. "The World of Concrete Contents", in Inquiry: An Interdisciplinary Journal of Philosophy and the Social Sciences 28, pp. 417 - 428 ;Naess, A., 1987, "SelfRealization: An Ecological Approach to Being in the World", in The Trumpeter 4(3): pp. 35 - 42 33. Martell, L., p. 4

34. Ibid., p. 8

35. Ibid., p. 13

36. Ibid., p. 13

37. Ibid., p. 14

38. Ibid.

39. Ibid 


\section{Bibliography}

Barry, J., 2004. "Green Political Theory" in Political Ideologies: An Introduction, eds. V. Geoghegan, and R. Wilford, London: Routledge.

Carson, R., 1962. Silent Spring. New York: Houghton Mifflin Company.

Carter, N., 2001. The Politics of the Environment Ideas, Activism, Policy, UK: Cambridge University Press.

Devall, B., and George, S., 1985. Deep Ecology: Living as if Nature Mattered. Salt Lake City, UT: Peregrine Smith

Dobson, A., 1995. Green Political Thought: An Introduction, $2^{\text {nd }}$ ed., London: Routledge.

Dobson, A., 2000. Green Political Thought, $3^{\text {rd }}$ ed., London: Routledge.

Dobson, A., 2007. Green Political Thought, $4^{\text {th }}$ ed., London: Routledge.

Eckersley, R., 1992. Environmentalism and Political Theory: Toward and Ecocentric Approach. London: University College London Press.

Humphrey, M., 2001. "Reassessing Ecology and Political Theory" in Environmental Practices, 10.

Hoffman, J. And Graham, P., 2006, Introduction to Political Ideologies. UK: Pearson Education Limited.

Irvine, S., and Ponton, A., 1988. A Green Manifesto, London: Macdonald Optima.

Marien, M., 1977. "The Two Visions of Post-Industrial Society" in Future 9 (5).

Meadows, D. L., and Meadows, D. H. et al., 1974. The Dynamics of Growth in a Finite World, Cambridge: Wright-Allen Press, Mass.

Meadows, D. H., Meadows, D. L., and Jorgen, R., 1992. Beyond Limits: Confronting Global Collapse, Envisioning a Sustainable Future. White River, VT: Chelsea Green Publishing Company,

Martell, L., 1994. Ecology and Society: An Introduction. Cambridge: Polity Press.

Naess, A., and Sessions, G., 1984. Basic Principles of Deep Ecology, www.deepecology.org, retrieved on $5^{\text {th }}$ August, 2017.

Naess, A., 1985. "The World of Concrete Contents", in Inquiry: An Interdisciplinary Journal of Philosophy and the Social Sciences 28.

Naess, A., 1988, "Self-Realization: An Ecological Approach to Being in the World", in The Trumpeter 4(3).

Naess, A., 1989. Ecology, Community and Lifestyle: Outline of an Ecosophy, trans. David Rothenberg, New York: Cambridge University Press.

Lovelock, J. E., 1989. The Ages of the Gaia. Oxford: Oxford University Press.

Porrit, J., 1984. Seeing Green: The Politics of Ecology Explained, Oxford: Basil Blackwell, Wall, D., 1994. Green History: A Reader in Environmental Literature, Philosophy, and Politics. UK: Routledge Publisher. 